\title{
Job Contract at Birth of the First Child as a Predictor of Women's Labor Market Attachment: Trajectory Analyses over II Years
}

\section{Laura Peutere'}

Doctoral student, University of Tampere, School of Health Sciences, Finland

\section{Jussi Vahtera}

Professor, University of Turku, Department of Public Health, Finland

\section{Mika Kivimäki}

Professor, University College London, Department of Epidemiology and Public Health, UK

\section{Jaana Pentti}

Statistician, Finnish Institute of Occupational Health, Finland

\section{Pekka Virtanen}

Senior research fellow, University of Tampere, School of Health Sciences, Finland

\begin{abstract}
There is a lot of evidence that pre-birth employment and access to parental leave are important predictors of mothers' labor market attachment after childbirth. This register-based study from Finland aimed to analyze in which ways the type of job contract (none, temporary, or permanent) at the start of maternity leave predicts labor market attachment in the long term. The mother cohorts were followed up for I I years. Labor market attachment was analyzed with latent class growth analysis, which makes it possible to identify subgroups with differing track and level of development. Lack of employment and having a temporary contract at baseline were associated with slower and weaker labor market attachment irrespective of mother's age, socioeconomic status, and subsequent births. These findings suggest that the polarization of women into the core and periphery of the labor market structure tends to continue after the birth of the first child. Temporary employment might be an obstacle for having rights for a job-protected family leave and have long-term consequences on the continuity of employment and the division of paid and unpaid work in the family.
\end{abstract}

\section{KEY WORDS}

Finland / labor market attachment / latent class growth analysis / mothers' employment / temporary employment

\footnotetext{
1 Laura Peutere, University of Tampere, School of Health Sciences, Finland, Email: laura.peutere@uta.fi
} 


\section{Introduction}

rior research has shown that working during pregnancy and being eligible for parental leave are related to stronger labor market attachment after birth (e.g., Brugiavini et al., 2013; Burgess et al., 2008; Fagan \& Norman, 2012; Hoffert \& Curtin, 2006). However, there is less research on the role of the employment contract prior to childbirth in later employment outcomes in the long term, and especially whether one has been working on a permanent or temporary basis (Baxter, 2009; Bonet et al., 2013; Bratti et al., 2005; Gutiérrez-Domènech, 2005; Saurel-Cubizolles et al., 1999). This is important as the right to keep a job after childbirth does not necessarily apply to temporary employees.

Nordic countries are often viewed as leaders in family-friendly policies, with a high female employment rate (see Datta Gupta et al., 2008). On the other hand, differences in labor market participation between men and women, and among subgroups of women, remain even here. The present study was set up to analyze patterns of labor market participation and their determinants after the birth of a woman's first child in one of the Nordic countries, Finland.

In contrast to the other Nordic countries, the Finnish system of family leave has been characterized as being among the least flexible, leading to relatively long periods out of the labor market (Datta Gupta et al., 2008; Rønsen \& Sundström, 2002; see also Boje \& Ejrnæs, 2012). In Finland, there are restrictions for taking family leave parttime, saving leave for later use, and working between leave periods (Salmi \& LammiTaskula, 2014). In Sweden, for example, the days of parental leave can be taken flexibly full-time or part-time, and saved for later use until the child is 12 years old (Duvander et al., 2014). On the one hand, also in Finland, these periods out of the labor market are mainly temporary: the employment rate for mothers with children from 3 to 6 years old is nearly $80 \%$, and the rate rises almost to the same level as that for fathers, $90 \%$, when children grow older (Statistics Finland, 2013a). On the other hand, a large proportion of young women of childbearing age work temporarily, especially in the public sector (Lehto \& Sutela, 2009), and almost $40 \%$ of mothers with a child under 1 year old caring for their children at home do not have a valid employment contract (Statistics Finland, 2013 b). While the majority of mothers return to employment in a few years after childbirth, the effects of childbirth on employment might be worse among those with weaker labor market status before the childbirth-an association not visible in the average figures. The purpose of this study is to analyze the importance of the employment contract (none, temporary, or permanent) at the time of the first birth for mothers' labor market trajectory with a follow-up over 11 years.

\section{Background}

\section{I Labor market and family policy context in Finland}

In Finland, the family benefits that enable the integration of family life and participation in the labor market are relatively generous (see Tab. 1). There is a 4-month period of earnings-related maternity leave that is stipulated for the mother; about 1 month before, and 3 months after childbirth. The earnings-related parental leave of 6 months has to 
Table I Summary of the family leave in Finland

\begin{tabular}{l|l}
\hline Mother & Father \\
\hline Earnings-related maternity & \\
leave starts 30-50 days & \\
before the estimated date & \\
of birth. The leave is in & \\
total 105 working days. & \\
\hline
\end{tabular}

Child birth/estimated date of delivery

\begin{tabular}{ll|l}
\hline Child is about 0-3 months & $\begin{array}{l}\text { The maternity leave } \\
\text { continues about } 3 \text { months } \\
\text { after birth. }\end{array}$ & $\begin{array}{l}\text { Earnings-related pater- } \\
\text { nity leave is } 54 \text { working } \\
\text { days. At maximum, }\end{array}$ \\
\hline Child is about 3-9 months & $\begin{array}{l}\text { Earnings-related parental leave (158 working can be used } \\
\text { days, i.e., about } 6 \text { months) can be divided } \\
\text { between the parents. Part-time leave is the mother is } \\
\text { possible only if both parents reduce their } \\
\text { working hours and take partial leave at the } \\
\text { same time. }\end{array}$
\end{tabular}

Child is about 9 months

-> 2nd birthday
The rest of the paternity leave can be used only after the parental leave has been used in total. It is available until the child turns 2 years old.
Child is about 9 months

-> 3rd birthday
Mother or father can take child home care leave and receive home care allowance (34I.06 EUR in 2014), with possible additional means-tested, sibling, and municipal supplements.
Child is 9 months -> child's second school year ends

\begin{abstract}
Parents can take partial child care leave and work reduced hours (available for those who have been employed at least 6 months for the same employer within a previous year). For a child under 3 years of age, parents can receive flexible care allowance (since 20I4). For a child in Ist and 2nd grade in school, parents can receive partial home care benefit.
\end{abstract}

Sources and further details: Salmi \& Lammi-Taskula 20I4; Social Insurance Institution of Finland (http://www.kela.fi/web/ en/families); Employment Contracts Act, Health Insurance Act, Act on Child Home Care Allowances and Private Care Allowances.

be taken after the maternity leave, and can be divided between the parents as they wish. After parental leave, when the child is about 9 months, either one of the parents can take home care leave until the child's third birthday. For fathers, there is a paternity leave of 9 weeks that can be taken until the child turns 2 years old. After the parental leave, public childcare (or a benefit for private childcare) is available to all families until the child goes to school (see Salmi \& Lammi-Taskula, 2014). In practice, mothers use most of the family leave that could be divided between parents. Mothers are continuously on leave on average 20 months per one child (including a 2 month's break at maximum) (Haataja \& Juutilainen, 2014: 28-29). In this study, we use "family leave" to refer to both maternity, paternity, and parental leave and home care leave in general in Finland. 
When referring to previous research, we, however, use the terms used in the studies in question.

An important phenomenon in the Finnish labor market, related to the use of family leave, is the use of fixed-term job contracts. The proportion of Finnish women working temporarily is $18 \%$ and of men is $12 \%$, whereas in other European Union (EU) countries, the difference in employment in temporary work between the genders is smaller on average (14\% and $13 \%$, respectively) (Eurostat, 2014). Fixed-term work is most common in the female-dominated public sector, in education, social work, and healthcare. Furthermore, sequential fixed-term job contracts for the same employer are more common for women than for men (Lehto \& Sutela, 2009). As women more commonly have fixed-term jobs than men, parents' choices regarding family leave are often "made in the context of the father's stable versus the mother's unstable career" (Närvi, 2012: 467). On the other hand, in the municipal (i.e., local government) sector, there is a constant need for substitutes. Many of the jobs are statutory and have to be carried out during parental and sick leave (Palanko-Laaka, 2005: 39), ensuring that temporary jobs at least are available.

In Finland, women traditionally work full-time (see e.g. Pfau-Effinger, 1993). Working part-time is less common $(19 \%)$ than for women in the European Union countries on average (32\%) (Eurostat, 2014; see also Lehto \& Sutela, 2009). However, mothers of young children would often prefer working part-time instead of full-time (Hakovirta $\&$ Salin, 2006), but it is not always possible. Parental leave cannot be taken part-time unless both parents take part-time leave. Also, after parental leave, the opportunity to work reduced hours for the purposes of childcare has been granted only to those who have had the same job at for at least 6 months and not for those trying to find a new job after childbirth. This makes it more difficult for mothers with no valid job contract or with temporary jobs expiring during the period of family leave to combine work and family (see also Närvi, 2012).

This situation in the labor market is also reflected in the debate about child home care. On the one hand, users strongly support home care, while on the other, the scope for reconciling work and care is criticized (Repo, 2010: 53). It is also widely believed in Finland that small children should first be cared for at home (Pfau-Effinger, 2012). In addition to the problems associated with combining full-time work and care, there are strong cultural incentives toward home care, which together lead to longer periods out of the labor market.

\subsection{Return to employment after childbirth}

Previous research has shown that women working during pregnancy and returning to employment relatively soon after childbirth have stronger attachment to the labor market in the long term than other women (e.g., Fagan \& Norman, 2012; Shapiro \& Mott, 1994). In addition, women with higher education or a higher occupational position return to work sooner (Fagan \& Norman, 2012; Vlasblom \& Schippers, 2006), which might partly indicate stronger preferences for paid work both before and after childbirth.

Returning to work after childbirth is also highly related to the right to parental leave and to keep their old jobs. In some countries, the number of working hours or the length of service for the same employer, for example, are (or have been) related to the 
right to parental leave and job protection, and therefore promote job continuity around childbirth (e.g., Burgess et al., 2008; Hoffert \& Curtin, 2006).

Only a few studies have considered the type of contract-whether permanent or temporary-preceding the birth of a child. An Australian study found that women with a permanent job contract were more likely to return to the labor market than women with a casual or fixed-term job during the 18 months after the birth (Baxter, 2009). The permanent employees had more often taken parental leave (or had the opportunity to do that), whereas for casual and fixed-term employees, this was more unlikely. SaurelCubizolles et al. (1999) also found that women with fixed-term job contracts were less likely to return to work than permanent employees a year after childbirth in Spain, Italy, and France. Other studies conducted in Spain obtained comparable results, with a 6-9 months follow-up (Gutiérrez-Domènech, 2005) and with a 1-year follow-up after childbirth (Bonet et al., 2013). Both of these studies indicate that temporary workers are less likely to be employed after childbirth. Bratti et al. (2005) found that Italian women working on both a permanent and a temporary basis before childbirth were as likely to be in the labor force 3 years after the first birth. The reason for this result might be that the outcome variable-labor force participation — combined women both employed and unemployed (versus those out of the labor market).

In summary, previous studies indicate that temporary jobs are related to weaker attachment to the labor market after childbirth. Although temporary employment among women is very common in Finland, there is little research on its effects on women's labor market attachment after the advent of parenthood. A study based on a survey in 2013 found that those with a valid job contract at the time of the childbirth were more commonly employed at about 2 years after the birth of a child, as well as were those with a permanent job contract compared with those with only a temporary job (Närvi, 2014b). A register-based study of women who gave birth in 1998 found that fixed-term employment was typical for women not using the home care allowance at all (i.e., not staying on home care leave after parental leave when the child is about 9 months old), or postponing it to a later occasion. Women with a secure labor market status were able to use the home care allowance more flexibly and plan their leave periods depending on other circumstances in the family. Moreover, it was typical for women with previous unemployment periods to use the allowance for as long as possible and also to end up being unemployed after the home care period (Rissanen, 2012). A qualitative study among Finnish parents found that mothers with unstable employment situation were concerned about their future career after childbirth; some of them started applying a new job relatively soon or accepted a job offer to guarantee their chances in the labor market. Others with a long temporary contract felt obligated to return to work when the contract was still effective. At the same time, it was typical for the mothers to feel pressure to take care of their child(ren) at home as long as possible. Moreover, for some of them, lack of a job contract meant that they did not have to plan the return to work in advance (Närvi, 2014a: 125-137).

\subsection{Methodological issues for analyzing women's employment patterns around the start of parenthood}

Various study designs and methods have been applied in longitudinal analyses of the impacts of childbirth on women's employment. There are a number of studies that analyze 
the average employment patterns with respect to known background variables, such as education, country, age, or age cohort. For example, Fouarge et al. (2010) have studied mothers' employment on the basis of survey data from Germany, the Netherlands, and Great Britain 2 years before and 20 years after childbirth. The study showed that women's participation in the labor market decreases before the birth but increases after the birth, following "a saddle-shaped pattern." Although younger age cohorts have a higher participation rate than older cohorts, the rates do not recover to the same level as before the birth (Fouarge et al., 2010).

Some studies have applied methods that enable identification of clusters or subgroups following different employment patterns (Aassve at al., 2007; Simonson et al., 2011). Combining retrospective and panel data, Aassve et al. (2007) identified nine work-family patterns among British women between the ages of 13 and 30 . The authors conclude that the trajectories indicating "work-oriented" preferences seemed to prevail among these young women, whereas evidence for the existence of women with pure family orientation remained scarce. Simonson et al. (2011) analyzed the life histories of German women between the ages of 15 and 45 and identified four clusters, characterized by the predominance of full-time employment, discontinuous employment, parttime employment, or housewife status.

In addition, latent class growth analysis and growth mixture modeling have been used in the analysis of employment trajectories in general (e.g., Huang et al., 2011; Virtanen et al., 2011), and in particular for men or women (Dariotis et al., 2011; Hynes \& Clarkberg, 2005). Hynes and Clarkberg (2005) analyzed women's employment trajectories around the time of childbirth in the USA. They identified six different types of employment patterns surrounding first and second births, ranging from continuously employed to continuously out of the labor market. The follow-up time after both births was 2 years (Hynes \& Clarkberg, 2005).

In summary, research on women's employment patterns surrounding the start of parenthood that combines both the type of contract preceding childbirth and a long follow-up time is limited. In addition, using methods that enable the distinguishing of latent classes in the data may reveal different features in the development of labor market attachment that would remain unobserved when focusing only on previously known background factors and average levels of attachment. The present study applies latent class growth analysis to the examination of women's labor market attachment with a relatively long follow-up time and register-based data. In addition, research conducted in specific countries may not be transferable to different labor markets and family policy contexts. This study contributes to the research on mothers' employment outcomes in the contexts set by the Nordic type of welfare state and a high rate of fixed-term job contracts, especially among women of childbearing age.

\section{The aims of the study}

The aim of this study is to elicit different trajectories for labor market attachment subsequent to the first childbirth, taking into account the labor market status prior to maternity leave. Women with and without a job contract when the leave started are studied separately. Having obtained a relevant set of trajectories, we analyze their associations with the job contract (permanent or temporary) prior to the birth. 
Our hypothesis is bidirectional. According to previous survey and register-based studies reviewed above, it may be expected that—compared with permanent employmentprevious temporary employment predicts delayed and weak labor market attachment after the birth. On the other hand, based on the qualitative study among Finnish parents (Närvi, 2014a), an opposite result could also be possible; women with a temporary contract or unstable labor market status preceding childbirth are more reluctant to stay at home for a long time, as this might lead to increasing difficulties for re-entry to the labor market.

\section{Data and methods}

\section{I The sample}

The sample for the present study was derived from the Finnish Public Sector Study (FPSS) that follows up the employees of 10 urban municipalities and six hospital districts in Finland (see e.g. Kivimäki et al., 2009). The study is based on an open cohort, meaning that new employer cohorts have been included to the study regularly. The study includes employees who have been employed for at least 6 months in any year between 1991 and 2005 ( $\mathrm{n}=151,901)$ in the municipalities. The FPSS has been approved by the ethics committee of the Hospital District of Helsinki and Uusimaa.

The study cohort included the women who, according to the Finnish Care Register for Health Care, had their first birth in the years 2000-2002 ( $\mathrm{n}=3,835$ ). This register contains data on hospital visits covering the whole country (Sund, 2012). Using the information from the National Pension Register (see section 4.2), the cohort obtained was divided into two subgroups according to labor market status (employment contract or not) at the time of the birth. Further criteria for being included in the subgroup were as follows. The subgroup without a contract at the time of the birth included women who had been employed in the municipalities or hospitals within a 5 -year period before the birth. The subgroup with a contract included those who were employed in the municipalities or hospitals at the time of the birth. Women employed somewhere other than in the municipalities or hospitals $(n=690)$ at the time of the first birth were excluded from the analysis, as information on the type of employment contract was not available. In addition, four women who died during the follow-up were excluded from the analysis. The final number of women included in the study was 3145, 1532 not employed and 1613 employed at the time of the birth of their first child.

\subsection{Variables}

The type of job contract prior to the first birth was defined on the basis of the information in the personnel registers of the municipalities and hospitals. For the cohort of women with a valid job contract at the time of the birth, this variable indicates whether they started the maternity leave under a permanent or a temporary contract. For women not employed, the variable indicates the nature of their job contract (permanent or temporary) during the most recent period in the service of the employer. In the present study, 
temporary employment refers to fixed-term jobs, that is, job contracts with a limited duration for any reason, such as substitution.

The measure of labor market attachment was based on data obtained from the National Pension Register managed by the Finnish Centre for Pensions. The register includes information on all work in both public and private sectors, and work on a selfemployed basis, that is insured according to the Earnings-related Pension Acts. ${ }^{1}$ As all work has to be insured, the register data can be regarded comprehensive. The start and end days of employment periods are recorded to the register according to the information given by the pension insurance companies and other institutions.

Employment periods, that is, the periods person has been insured from 2000 to 2011 were included. The periods were recorded to an accuracy of 1 month on the basis of the information on start and end days. Labor market attachment was measured as the number of months worked per 6 months. Therefore, the data consisted of 18-22 variables with values ranging from 0 to 6 . The follow-up lasted 9-11 years, starting from the month following the first birth.

As a general rule, maternal (about 4 months) and parental (about 6 months) leave from permanent (or long temporary) jobs are not reported to the Finnish Centre for Pensions and therefore do not appear as breaks in the continuity of employment contracts. Therefore, the proportion of women attached to the labor market is artificially high, especially among women who were employed at the time of the first birth. As the employment recorded to the register also includes some periods when the person actually is not attending at work, the term "labor market attachment" instead of "employment" describes the variable more exactly.

A variable indicating socioeconomic status is based on the personnel registries of the employer. Information on employees' occupation available in the registries has been coded according to the classification of Statistics Finland (Statistics Finland, 1987). It is categorized into upper-level white collar, lower-level white collar, and blue collar workers. The socioeconomic status indicates both the educational and the occupational status of women included in the data. The majority of upper-level white collar workers included in this data are teachers in kindergartens and schools, and doctors, occupations requiring a university degree. The main occupations among lower-level white collar workers are nurses in hospitals and kindergartens. Blue collar workers are mainly assistants in hospitals, cleaners, and kitchen staff.

Age is also based on the information retrieved from the personnel registries. It is treated as a continuous variable. As for the first birth, information on the number of subsequent births during the follow-up is based on the dates of births available in the Care Register for Health Care. The values of this covariate range from 0 to 4.

\subsection{Statistical methods}

We used latent class growth analysis as the principal method (Nagin, 2005). This method requires that the same individuals (or any other observational units) are followed over age or time, so that there are measures from different time points available. The purpose is to find clusters of individuals that follow the same kind of patterns over time. For example, there might be a subgroup of individuals who have an increasing pattern in the measured property during the follow-up, or those whose values do not change at all. These different developmental patterns are "hidden" in the data. The purpose is 
to identify a proper number of hidden patterns and their shapes from the data so that each individual follows one of the patterns as closely as possible. This means that the aim is to find a solution in which the probability for each individual to be classified in one track is as high as possible, whereas the probability to belong to any other track is as low as possible. The solution should also be as simple as possible; the aim is to find the lowest number of distinctive patterns with the best fit for each individual. The best solution can only be identified by trying out different models, comparing different statistical criteria and interpreting visually the emerging trajectories (Jung \& Wickrama, 2008; Nagin, 2005).

The distribution of the variable used has to be taken into account when modeling the data. In the present study, the number of months worked during every 6-month period is a count that can be analyzed by applying Poisson distribution. The distribution of the variable is skewed, as up to $96 \%$ of the women have been attached to the labor market for a full $6 / 6$ months. Therefore, a zero-inflated Poisson (ZIP) distribution was used in the analyses (e.g., Lambert, 1992; Nagin \& Land, 1993). The values of the outcome variables were recoded so that the highest value 6 (months worked per half-year period) is equal to 0,5 is equal to 1,4 is equal to 2 , and so on, to make it possible to apply the ZIP models in the analyses.

Development of labor market attachment was assumed to be nonlinear; therefore, quadratic growth model was applied for all models and groups extracted. The models were compared with Bayesian information criteria (BIC), with a Lo, Mendell, and Rubin (LMR) likelihood ratio test (Lo et al., 2001), comparing k and k-1 class models (Nylund et al., 2007), and with substantive criteria (Nagin, 2005).

In latent class growth analysis, the assignment of individuals into different trajectories is based on (highest) probabilities. For example, as a result of the analysis, the probability for an individual to belong to a certain latent trajectory might be $91 \%$ - and regarded as the most likely latent class-while at the same time, the individual's probability to belong to all other classes is in total $9 \%$. Thus, in most cases, there is always some uncertainty within the classification. Therefore, we analyzed the distribution of independent variables in the latent trajectories with Wald test using pseudo-class method that utilizes information on the posterior probabilities (Mplus Technical Appendices, 2010; Muthén \& Muthén, 1998-2012). With pseudo-class method, the uncertainty related to the membership in latent classes is taken into account in a similar manner, as multiple imputation is done in missing data analysis to estimate the missing value (Clark \& Muthén, 2009). The effect of the independent variable (i.e., temporary versus permanent job contract) on the latent class membership in the model was estimated with and without covariates in multinomial logistic regression. The analyses were conducted with Mplus version 7 (Muthén \& Muthén, 1998-2012).

\section{Results}

\section{I Descriptive findings}

The majority (94\%) of the women who were not employed at the time of the first birth had had a temporary job contract in municipalities and hospitals. Among the women who were employed at the time of the first birth, $69 \%$ had a permanent and $31 \%$ a temporary contract. 
Table 2 shows the proportion of women employed for $6 / 6$ months during the follow-up, according to labor market status and job contract. Only a small proportion of women $(4.3 \%)$ not employed at the time of the birth and having had a temporary job in the past returned to employment during the second 6-month period after the birth, and 3 years later almost half of them were employed for $6 / 6$ months. Women with past experience of a permanent job returned more quickly to the labor market.

In contrast, on average, over $95 \%$ of women having a permanent employment contract at the time of the first birth maintained maximum labor market attachment throughout the 11-year follow-up time. The proportions of maximum attachment are also high for women with a temporary job contract at the time of the first birth, but not as high as for women with a permanent job. The high proportion even in the first half-year period (see Tab. 2) means that the contracts continued to be valid, and therefore, the maternity and parental leave do not appear as breaks in the register based on employment contracts.

Table 2 also shows that subsequent births take place most commonly between the second and fourth year after the first birth, after which the percentage of births decreases. There are some differences in the proportions and timings of subsequent births between the subgroups. Women not employed at the time of the first birth and with a past experience of a permanent job were less likely to have a second birth during the second year of the follow-up compared with women with a past experience in a temporary job. Also, women with a permanent job at the time of the first birth were less likely to have subsequent children in the third and fourth year of the follow-up than those with a temporary job.

A quarter $(25.7 \%)$ of women not employed at the time of the first birth are upperlevel white collar workers, a majority $(61.4 \%)$ are lower-level white collar workers, and $12.8 \%$ are blue collar workers. The corresponding proportions for women employed at the time of the first birth are somewhat different: $39.7 \%, 52.8 \%$ and $7.6 \%$, respectively.

Women employed at the time of the first birth are older (mean 31.5, range 20-49 years) than women not employed (mean 28.4, range 19-46 years).

\subsection{Analysis of women not employed at the time of their first birth}

A latent class growth model with two to six groups was conducted among women not employed at the time of the first birth. Although the fit indices (BIC and LMR Likelihood ratio test) improved as more classes were extracted, a model with four classes was chosen on the basis of substantive criteria (Fig. 1). It was possible to identify trajectories of early strengthening $(26.2 \%)$, intermediately strengthening $(20.8 \%)$, slowly strengthening $(25.0 \%)$, and weakly strengthening $(28.0 \%)$ labor market attachment. In the last named group, the average attachment level stays low, whereas the remaining three groups only differ with respect to the time that elapses until the attachment attains full strength.

A sensitivity analysis was conducted among women who did not have more children during the follow-up $(n=435)$. In the four-class model, the form of trajectories was quite similar to that in the original model and there were only some differences between proportions of individuals assigned to each latent class (figure not shown). This indicates that the composition and type of latent classes are not merely a result of the timing of subsequent births. 
Table II Full (6/6 months) labor market attachment at the follow-up time periods, according to labor market status at the time of the first birth and frequencies of subsequent births by the period

\begin{tabular}{|c|c|c|c|c|c|c|c|c|}
\hline & \multicolumn{4}{|c|}{ Not employed at the time of first birth } & \multicolumn{4}{|c|}{ Employed at the time of first birth } \\
\hline & \multicolumn{2}{|c|}{$\begin{array}{l}\text { Past permanent } \\
\qquad(\mathrm{n}=9 \mathrm{l})\end{array}$} & \multicolumn{2}{|c|}{$\begin{array}{l}\text { Past temporary } \\
\qquad(\mathrm{n}=|44|)\end{array}$} & \multicolumn{2}{|c|}{$\begin{array}{l}\text { Permanent } \\
(n=1 \mid 15)\end{array}$} & \multicolumn{2}{|c|}{$\begin{array}{l}\text { Temporary } \\
(n=498)\end{array}$} \\
\hline $\begin{array}{l}\text { The follow-up } \\
\text { time periods }\end{array}$ & $\begin{array}{l}\text { Employed 6/6 } \\
\text { months (\%) }\end{array}$ & $\begin{array}{l}\text { Births } \\
\text { (\%) }\end{array}$ & $\begin{array}{l}\text { Employed 6/6 } \\
\text { months (\%) }\end{array}$ & $\begin{array}{l}\text { Births } \\
(\%)\end{array}$ & $\begin{array}{l}\text { Employed 6/6 } \\
\text { months (\%) }\end{array}$ & $\begin{array}{l}\text { Births } \\
(\%)\end{array}$ & $\begin{array}{l}\text { Employed 6/6 } \\
\text { months (\%) }\end{array}$ & $\begin{array}{l}\text { Births } \\
(\%)\end{array}$ \\
\hline Year I $a^{a}$ & 0 & 0 & 0 & 0 & 99.3 & 0 & 91.2 & 0 \\
\hline Year Ib & 27.5 & 0 & 4.3 & 0.5 & 95.8 & 0.4 & 82.9 & 0 \\
\hline Year 2a & 60.4 & $2.2 *$ & 30.5 & $8.5 *$ & 96.2 & 6.5 & 82.3 & 5.6 \\
\hline Year 2b & 71.4 & 9.9 & 40.0 & 13.2 & 96.0 & 12.3 & 84.1 & 15.3 \\
\hline Year 3a & 75.8 & 7.7 & 44.0 & 11.5 & 95.3 & $10.7^{*}$ & 85.1 & $14.7 *$ \\
\hline Year 3b & 74.7 & 14.3 & 47.7 & 10.4 & 96.6 & 9.1 & 83.3 & 9.8 \\
\hline Year 4a & 78.0 & 8.8 & 51.7 & 9.6 & 96.3 & $6.1 *$ & 85.5 & 9.0* \\
\hline Year 4b & 81.3 & 5.5 & 57.2 & 8.1 & 97.1 & $5.3 * *$ & 85.9 & $9.0 * *$ \\
\hline Year 5a & 80.2 & 5.5 & 62.2 & 5.7 & 96.9 & 6.2 & 88.6 & 4.6 \\
\hline Year 5b & 83.5 & 6.6 & 67.1 & 5.1 & 96.8 & 3.3 & 88.2 & 4.4 \\
\hline Year 6a & 84.6 & 5.5 & 70.4 & 4.9 & 96.1 & 2.9 & 90.8 & 4.0 \\
\hline Year 6b & 86.8 & I.I & 72.9 & 5.1 & 95.2 & 2.5 & 90.8 & 3.4 \\
\hline Year 7a & 86.8 & 3.3 & 75.6 & 4.4 & 96.1 & 3.1 & 90.6 & 4.4 \\
\hline Year 7b & 84.6 & 5.5 & 77.1 & 4.9 & 96.1 & 1.7 & 89.6 & 2.8 \\
\hline Year 8a & 84.6 & 3.3 & 78.0 & 3.1 & 95.7 & 2.0 & 89.6 & 2.6 \\
\hline Year 8b & 84.6 & 2.2 & 78.5 & 3.3 & 96.1 & 2.1 & 91.4 & 3.4 \\
\hline Year 9a & 83.5 & I.I & 80.3 & 2.1 & 95.4 & 1.0 & 92.4 & 1.6 \\
\hline Year 9b & 84.6 & 0 & 82.8 & 1.5 & 94.9 & 0.7 & 90.8 & 1.2 \\
\hline Year $10 a^{b}$ & 84.0 & 0 & 84.0 & 2.1 & 94.1 & 0.6 & 91.0 & 1.2 \\
\hline Year $10 b^{b}$ & 82.0 & 2.0 & 83.2 & 1.8 & 95.3 & 0.4 & 91.6 & 0.3 \\
\hline Year I I $a^{b}$ & 69.6 & 0 & 84.1 & 1.7 & 95.6 & 0.3 & 91.8 & 0.6 \\
\hline Year I Ibb & 69.6 & 0 & 85.0 & 0.4 & 96.2 & 0 & 95.6 & 0 \\
\hline
\end{tabular}

"For each year, "a" is the first 6 months and "b" is the second 6 months.

bThe number of observations for $10^{\text {th }}$ and $1 \mathrm{I}^{\text {th }}$ years are 50 and 23 (past permanent) and 957 and 473 (past temporary), respectively, for women not employed at the time of first birth. The number of observations for $10^{\text {th }}$ and $1 \mathrm{I}^{\text {th }}$ years are 716 and 341 (permanent) and 321 and 159 (temporary), respectively, for women employed at the time of first birth. For subsequent births: ${ }^{*} p<0.05, * * 2<0.01$. 
Figure I: Trajectories of labor market attachment among women not employed at time of first birth $(n=1532)$.

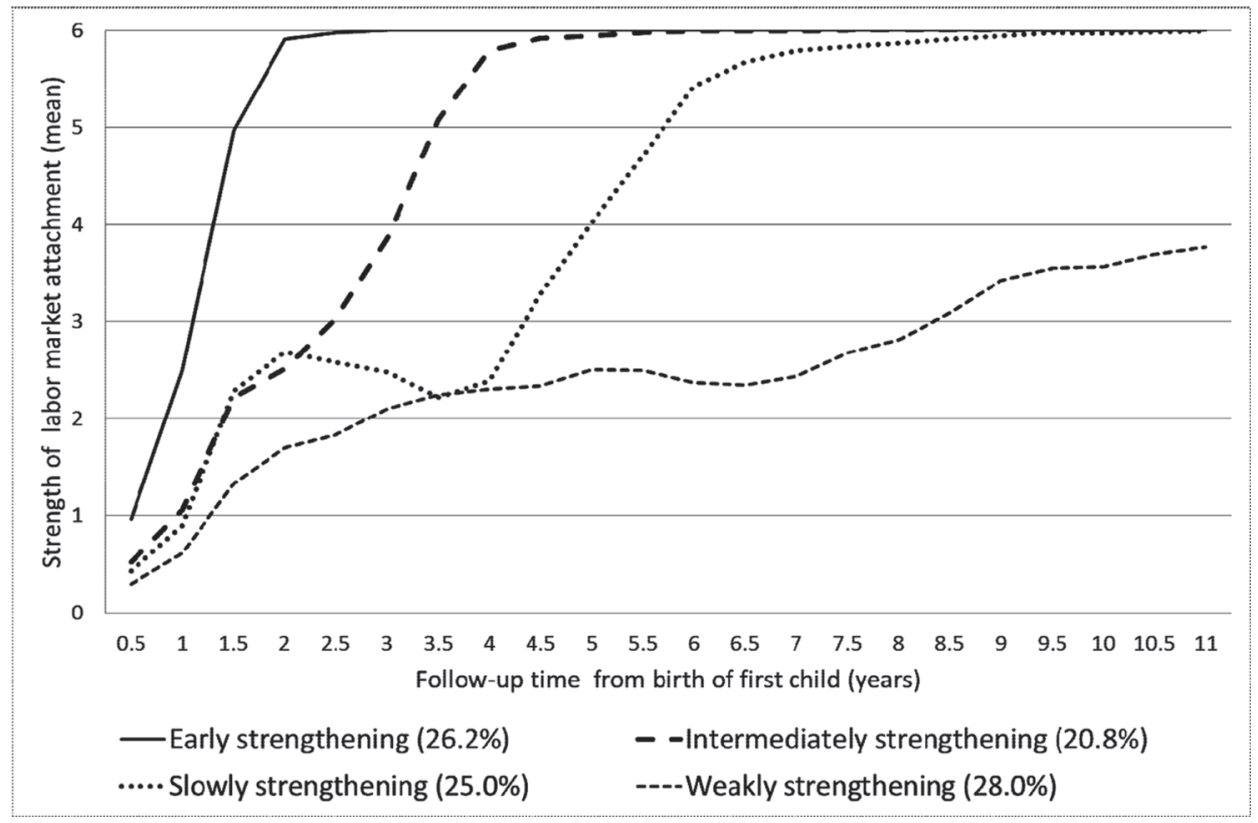

The type of job contract preceding the first birth and other independent variables were analyzed separately on the basis of the posterior probabilities from the four-class model. The proportion of temporary job contracts turned out to be relatively small $(87.3 \%)$ in the group of early strengthening trajectory (Tab. 3$)$. The groups also differ significantly with respect to age and socioeconomic status: on average, women assigned to the trajectory of weakly strengthening attachment are younger and belong more commonly to the category of blue collar workers. In addition, women assigned to the trajectories of slowly or weakly strengthening attachment had more children during the follow-up.

In line with the findings of Tab. 3, multinomial regression analysis with temporary employment as the only predictor shows that, compared with women with the trajectory of early strengthening labor market attachment, those with slowly, intermediately, and weakly strengthening labor market attachment are more likely to have had a history of temporary job contracts (Tab. 4, Model 1). In other words, even if they do not have a job contract at the time of the birth, those with a trajectory of early strengthening attachment have more often had a period of permanent employment in the past.

The effect of a previous temporary contract on the trajectory group remains after inclusion of socioeconomic status and age (Model 2) and the number of subsequent children (Model 3) in the analysis. In cases with weak labor market attachment, the odds ratios for temporary contract even increased after including the other covariates, whereas among trajectories of slowly and intermediately strengthening attachment, the changes in odds ratios are smaller. 
Table III Means of covariates in latent class trajectories of labor market attachment among women not employed at the time of first birth $(n=1532)$

\begin{tabular}{|c|c|c|c|c|c|}
\hline Covariates & $\begin{array}{c}\text { Early } \\
\text { strengthening }\end{array}$ & $\begin{array}{l}\text { Intermediately } \\
\text { strengthening }\end{array}$ & $\begin{array}{c}\text { Slowly } \\
\text { strengthening }\end{array}$ & $\begin{array}{c}\text { Weakly } \\
\text { strengthening }\end{array}$ & $\begin{array}{l}\text { Wald test } \\
\text { (p-value) }\end{array}$ \\
\hline & $\%$ or mean & $\%$ or mean & $\%$ or mean & $\%$ or mean & \\
\hline $\begin{array}{l}\text { Temporary job } \\
\text { (versus permanent) \% }\end{array}$ & 87.3 & 95.9 & 97.4 & 95.9 & $0.000 * * *$ \\
\hline Age (mean) & 29.2 & 28.7 & 27.9 & 27.7 & $0.000 * * *$ \\
\hline \multicolumn{6}{|l|}{ Socioeconomic status } \\
\hline $\begin{array}{l}\text { Upper-level white } \\
\text { collar workers \% }\end{array}$ & 27.9 & 30.3 & 25.8 & 20.3 & $0.020 *$ \\
\hline $\begin{array}{l}\text { Lower-level white } \\
\text { collar workers \% }\end{array}$ & 66.2 & 61.0 & 62.5 & 56.6 & 0.104 \\
\hline Blue collar workers \% & 5.9 & 8.6 & 11.8 & 23.1 & $0.000 * * * *$ \\
\hline $\begin{array}{l}\text { Subsequent children born } \\
\text { during the follow-up } \\
\text { (mean) }\end{array}$ & 0.84 & 0.88 & 1.04 & 1.34 & $0.000 * * * *$ \\
\hline
\end{tabular}

Table IV Labor market attachment of women not employed at time of first birth

\begin{tabular}{llccc}
\hline & & \multicolumn{3}{l}{ Trajectories of labor market attachment } \\
\hline & Early strengthening & $\begin{array}{l}\text { Intermediately } \\
\text { strengthening }\end{array}$ & Slowly strengthening & Weakly strengthening \\
\hline & OR $(95 \%$ Cl $)$ & OR $(95 \%$ Cl $)$ & OR (95\% Cl) \\
\hline Model I (a) & Reference & $3.69(1.85-7.37)$ & $5.61(2.69-11.67)$ & $3.44(1.94-6.11)$ \\
\hline Model 2 (b) & Reference & $3.79(1.89-7.60)$ & $5.30(2.47-11.35)$ & $3.78(2.04-7.00)$ \\
\hline Model 3 (c) & Reference & $3.81(1.91-7.61)$ & $5.53(2.58-11.86)$ & $4.01(2.17-7.42)$ \\
\hline
\end{tabular}

(a) Crude $(n=1532)$.

(b) Occupational status and age as covariates $(n=|, 53|)$.

(c) Occupational status, age and number of subsequent births as covariates $(n=1,531)$.

Odds ratios (ORs) and 95\% confidence intervals (Cls) from multinomial logistic regression with reference to the employment history (temporary versus permanent job) and to the trajectory of labor market attachment (early strengthening versus intermediately, slowly, and weakly strengthening trajectories).

Temporary employment was also related to intermediately, slowly, and weakly strengthening attachment in an analysis of women with no other children born during the follow-up (not in table).

\subsection{Analysis of women employed at the time of their first birth}

Latent class growth analyses with two to six groups were also conducted among women employed at the time of the first birth. In all models, a class of stable labor market 
Figure 2: Trajectories of labor market attachment among women employed at the time of first birth $(n=1613)$.

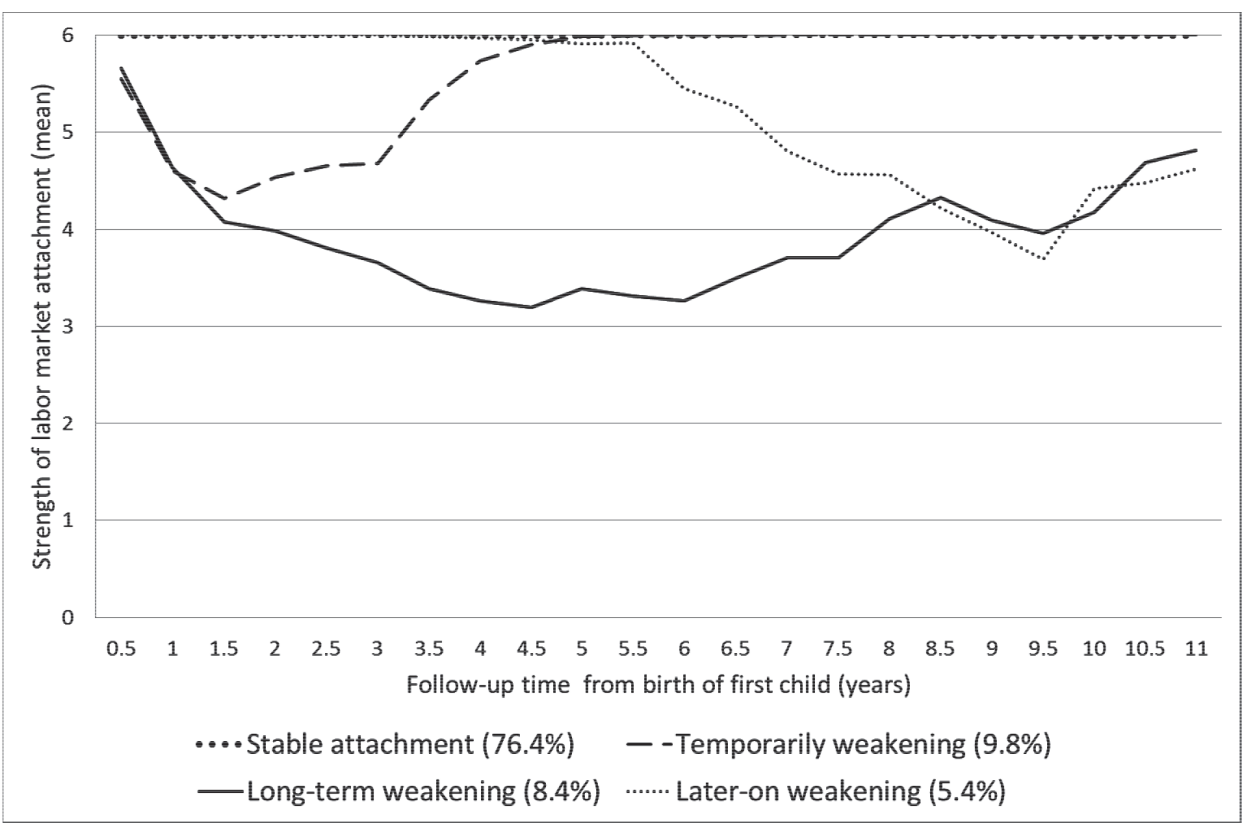

attachment, comprising $76-77 \%$ of the sample, was identified. Although the fit indices (BIC and LMR likelihood ratio test) improved as more classes were extracted, a model with four classes was chosen on the basis of substantive criteria (Fig. 2). In addition to the trajectory of stable labor market attachment $(76.4 \%)$, this model revealed the trajectories of temporarily weakening $(9.8 \%)$, long-term weakening $(8.4 \%)$, and later-on weakening attachment $(5.4 \%)$. Similar trajectories were also obtained in a four-class model among women who did not have more children during follow-up, with some differences in the proportions of individuals assigned to each class (figure not shown).

It was most common for women assigned to the long-term weakening attachment to have a temporary job contract at the time of their first birth (Tab. 5). Temporary job contract in the beginning of the follow-up was least common among women who maintained a stable attachment during the follow-up. The differences between other covariates across the classes are less prominent. On average, women assigned to stable attachment are older than others. A larger proportion of women assigned to long-term weakening attachment are blue collar workers, and women with later-on weakening attachment are less commonly upper-level white collar workers. Women with a stable attachment had fewer children during the follow-up.

With multinomial logistic regression, we compared the probability to have a certain labor market trajectory using stable attachment as the reference category and temporary employment as the explaining factor. Mothers who had a temporary job contract at the time of their first birth were more likely—than those with a permanent job—to have a 
TableV Means of covariates in latent class trajectories of labor market attachment among women employed at time of first birth $(n=1613)$

\begin{tabular}{|c|c|c|c|c|c|}
\hline Covariates & Stable & $\begin{array}{l}\text { Temporarily } \\
\text { weakening }\end{array}$ & $\begin{array}{l}\text { Long-term } \\
\text { weakening }\end{array}$ & $\begin{array}{l}\text { Later-on } \\
\text { weakening }\end{array}$ & $\begin{array}{l}\text { Wald test } \\
\text { (p-value) }\end{array}$ \\
\hline & $\%$ or mean & $\%$ or mean & $\%$ or mean & $\%$ or mean & \\
\hline Temporary job (versus permanent) \% & 25.3 & 49.1 & 57.8 & 32.6 & 0.000 ***** \\
\hline Age (mean) & 31.7 & 30.8 & 30.2 & 30.8 & $0.022 *$ \\
\hline \multicolumn{6}{|l|}{ Socioeconomic status } \\
\hline Upper-level white collar workers \% & 40.1 & 40.8 & 39.3 & 32.7 & 0.696 \\
\hline Lower-level white collar workers \% & 52.9 & 54.1 & 46.8 & 57.3 & 0.420 \\
\hline Blue collar workers \% & 7.0 & 5.1 & 13.9 & 10.0 & 0.103 \\
\hline $\begin{array}{l}\text { Subsequent children born during } \\
\text { the follow-up (mean) }\end{array}$ & 0.78 & 0.93 & 1.01 & 1.04 & $0.036 *$ \\
\hline
\end{tabular}

* $p<0.05$, ** $p<0.01$, *** $p<0.001$.

Table VI Labor market attachment of women having a valid employment contract at time of the first birth

\begin{tabular}{lcccc}
\hline & \multicolumn{4}{c}{ Trajectories of labor market attachment } \\
\hline & Stable & Temporarily weakening & Long-term weakening & Later-on weakening \\
\hline & & OR $(95 \%$ Cl) & OR $(95 \%$ Cl) & OR (95\% Cl) \\
\hline Model I (a) & Reference & $3.06(2.15-4.37)$ & $4.35(2.83-6.68)$ & $1.38(0.84-2.25)$ \\
\hline Model 2 (b) & Reference & $3.17(2.15-4.69)$ & $4.63(2.97-7.22)$ & $1.49(0.86-2.56)$ \\
\hline Model 3 (c) & Reference & $3.16(2.13-4.67)$ & $4.72(2.52-8.84)$ & $1.37(0.73-2.58)$ \\
\hline
\end{tabular}
(a) Crude.
(b) Occupational status and age as covariates.
(c) Occupational status, age, and number of subsequent births as covariates.

Odds ratios (ORs) and 95\% confidence intervals (Cls) from multinomial logistic regression with reference to the employment contract (temporary versus permanent job) and to the trajectory of labor market attachment (stable versus temporarily, long-term weakening, and later-on weakening trajectories) $(n=1613)$.

temporarily weakening or long-term weakening labor market attachment during the follow-up (Tab. 6). However, those with a temporary job contract in the beginning of the follow-up were not more likely to end up in the later-on weakening trajectory. The results change only a little after including socioeconomic status and age (Model 2) and the number of subsequent births as covariates to the model (Model 3).

Temporary employment was related to temporarily and long-term weakening attachment also among women who did not have more children during the follow-up (not in table). 


\section{Discussion}

The aims of the study were to define different trajectories for labor market attachment after the first birth and to examine whether the preceding job contract (none, temporary, or permanent) predicts the labor market attachment trajectory. Women with and without a job contract at the beginning of their maternity leave were studied separately. On the basis of the analysis, it can be concluded that a temporary job contract preceding the first birth—both at the time of the first birth and previously —is associated with weaker and delayed labor market attachment. Therefore, this study did not support the opposing hypothesis, that is, the assumption that women with previous temporary jobs would be more reluctant to stay at home for longer, as this might lead to increased difficulties for re-entry to the labor market.

The result is in line with previous studies with shorter follow-up times conducted in other European countries and Australia; those with a temporary job contract are less likely to be employed after giving birth than those with a permanent contract (Baxter, 2009; Bonet et al., 2013; Saurel-Cubizolles et al., 1999). The results also support those of the previous research on the use of family leave in Finland; those with weak labor market status and no job to return to after childbirth stay at home longer or are more likely to be unemployed after their leave (Närvi, 2014b; Rissanen, 2012). The present study also indicates that the weakening effects of temporary job contracts on labor market attachment after childbirth might be prolonged. Likewise, lack of an employment contract at the time of the birth is related to weaker and delayed attachment to the labor force. Absence from the labor market might also be prolonged by the fact that when trying to find a new job after a family leave period-when children are still small—it is more difficult to negotiate flexible or shorter working hours (Närvi, 2012). As noted previously, it is possible to take partial home care leave only for those who have been working for the same employer at least 6 months. It might also be more difficult to get a place in a day care in a short time and with a reasonable distance from home or work after getting a new job (Miettinen \& Manninen, 2006: 73-75). For those without a previous job contract, combining work and family becomes more complicated.

It is possible that those who had previously worked on a temporary basis might have had periods of unemployment and problems with finding a job after family leave. However, it was not possible to take unemployment into account in this study. On the other hand, the employment situation in the municipal sector is quite secure, and employees feel the threat of unemployment and layoffs less commonly compared with those in other employment sectors (Forma et al., 2008: 18). It may be assumed that in the municipal sector, the effects of longer periods out of the labor market are evident mainly in the accrual of earnings-related pensions. In the public sector in general, mothers seem to reach the wage level of women without children as they get older, whereas in the private sector, the wage difference remains between women with and without children (Kellokumpu, 2006: 51).

The follow-up time period was 11 years, including the first decade of the 2000s. There have been changes in the labor market during these years. For example, the unemployment rate decreased and the proportion of fixed-term employment decreased slightly during the study period among women in Finland (Statistics Finland, 2010a, 2010b). The economic crisis began during the end of the follow-up in 2008, and might have weakened employment possibilities of these women. On the other hand, as the 
crisis took place only in the end of the follow-up, it is not that relevant regarding the main findings of the present study. It is possible that in a different economic situation, the shape of the trajectories and proportions of individuals assigned to them would be different. This study focused on women with their first birth in 2000-2002, living in the same historical time period.

Four trajectories of labor market attachment were identified, among both women not employed and those employed at the time of the first birth. The majority of women $(76.4 \%)$ employed at the time of the first birth also remained attached to the labor force during the follow-up time, whereas women not employed at the time of the first birth were more evenly assigned to the four different trajectories. A smaller proportion $(72 \%)$ of women not employed at the time of the first birth had reached a stable attachment after the follow-up time of 11 years compared with those who were employed at the time of the first birth $(86 \%)$. This finding is in line with that of previous research; being employed around the time of the first birth is related to more stable labor market attachment after the birth in the long term (e.g., Shapiro \& Mott 1994).

This is one of the first studies applying LCGA in research on mothers' employment around parenthood (see also Hynes \& Clarkberg, 2005; Peutere et al., 2014). As regards the statistical methods used, the LCGA seemed to work well with the data. Trajectories with different patterns were identified, indicating that the method revealed features that had remained unobserved if we had focused only on average growth curve or used other methods for longitudinal data, such as survival analysis. Another advantage is in visually meaningful presentation of the developmental trajectories and their proportions in the study population (Nagin, 2005: 185). The probabilities for most likely latent class membership were high on average (over $90 \%$ ), also indicating a good model fit.

None of the trajectories identified showed a complete exit out of the labor market during the 11 years of follow-up. This might be due to the fact that all of the women in this study had had some work experience in municipalities or hospitals prior to the first birth, and were to some extent attached to the labor market. On the other hand, among mothers, remaining a housewife for a long period is rare in Finland; in the majority of families with two parents, both of them are employed when children grow older (Statistics Finland, 2013a).

The strengths of the study relate to register-based data with a long follow-up time. Combining data from employers' personnel registers, the National Pension Register, and Care Register for Health Care, it was possible to analyze women's labor market trajectories after the first birth with a follow-up time of 11 years. With register-based data, the problems of selection, missing data, and recall bias were avoided.

The data relating to the first and possible subsequent births are based on the Care Register for Health Care. Although the register data can be regarded as a reliable source of information on births in Finland, it is possible that for some of the women, the birth was not the first one; they might have given birth previously or during the follow-up while abroad, or adopted a child, for example.

There are some limitations to the measure of labor market attachment that are related to the register data and Finnish pension system. Information on the nature of the job contracts is not available (e.g., working full-time or part-time). Furthermore, the data do not include information on periods out of the labor market, such as unemployment and studying, or long periods of work abroad or undeclared work. However, the register data can be considered a good measure of labor market attachment-not 
employment as such-irrespective of unpaid periods out of the labor market. It is possible that women with a weak attachment to labor market also more commonly have part-time or temporary jobs than women with a stable attachment.

It is also possible that a woman not employed at the time of the first birth, and recorded as having only a temporary job in municipalities or hospitals preceding the first birth, had had a permanent job in another municipality or in the private sector. Therefore, the group of women recorded as having a temporary job may also include women with an experience in permanent jobs. Despite this possible underestimation of permanent jobs among women not employed at the time of the first birth, previous experience on a temporary job contract seemed to be associated with weaker and delayed labor market attachment.

Finally, one limitation of this study relates to the lack of information of the possible partner's employment situation. The decisions on work and care are made in relation to the partner's position in the labor market. For example, Fagan and Norman (2012) showed that lone mothers and mothers whose partner was not employed were more likely employed full-time than part-time when the child was 3 years old. In addition, mothers with partners working long hours were less likely employed at all 3 years after childbirth.

\section{Conclusion}

This study shows that unstable labor market status-that is, lack of employment or temporary employment-preceding the first birth is associated with mothers' weaker labor market attachment after giving birth, irrespective of the mother's age, socioeconomic status, and possible subsequent births. However, it must be noted that these results apply to a Nordic type of welfare context, with universal rights to child day care, relatively generous family benefits, and a large public sector offering employment opportunities for women. In any case, these findings suggest that the polarization of women into the core and periphery of the labor market structure tends to continue after the birth of the first child. This finding is also relevant internationally, as the proportion of female temporary employment is also significant in many other European countries, such as Spain, Poland, and Sweden (Eurostat, 2014). In Finland, municipality might not be such a secure employer in the near future, as structures of the social and health services will be renewed, outsourcing to private firms seems to increase, and the public sector is forced to implement austerity measures. This may mean increased threats of losing employment contracts, also around the family leave, in particular among the temporary employees.

Among the main objectives of the European Union are to improve gender equality in working life and raise female employment rate. Although family leave support combining parenthood and paid employment, these are not equally available for all groups in the labor market. Temporary employment might be an obstacle for having rights for a job-protected family leave and have long-term consequences on the continuity of employment and the division of paid and unpaid work in the family. Mother's temporary job contract expiring before or during the family leave might also in some cases be an obstacle for the father to take family leave as he has to be the breadwinner (Närvi, 2014a). Therefore, not only family leave and benefits but also the use of temporary employment should be taken into account when supporting combining work and childcare. 


\section{Acknowledgments}

This study was supported by the Academy of Finland (grant numbers 132668 and 264944).

\section{References}

Aassve, A., Billari, F.C. and Piccarreta, R. (2007) 'Strings of Adulthood: A Sequence Analysis of Young British Women's Work-Family Trajectories', European Journal of Population 23(3-4): 369-388. DOI: 10.1007/s10680-007-9134-6

Baxter, J. (2009) 'Mothers' Timing of Return to Work by Leave use and Pre-Birth Job Characteristics', Journal of Family Studies 15(2): 153-166. DOI: 10.5172/jfs.15.2.153

Boje, T.P. and Ejrnæs A. (2012) 'Policy and practice: The relationship between family policy regime and women's labour market participation in Europe', International Journal of Sociology and Social Policy 32(9/10): 589-605. DOI: 10.1108/01443331211257670

Bonet, R., Cruz C., Fernández Kranz, D. and Justo, R. (2013) 'Temporary Contracts and Work-Family Balance in a Dual Labor Market', Industrial \& Labor Relations Review 66(1): 55-87.

Bratti, M., Del Bono, E. and Vuri, D. (2005) 'New Mothers' Labour Force Participation in Italy: The Role of Job Characteristics', LABOUR: Review of Labour Economics \& Industrial Relations 19: 79-121. DOI: 10.1111/j.1467-9914.2005.00324.x

Brugiavini, A., Pasini, G. and Trevisan, E. (2013) 'The direct impact of maternity benefits on leave taking: Evidence from complete fertility histories', Advances in Life Course Research, 18(1): 46-67. DOI: 10.1016/j.alcr.2012.10.003

Burgess, S., Gregg, P., Propper, C. and Washbrook, E. (2008) 'Maternity Rights and Mothers' Return to Work', Labour Economics 15(2): 168-201. DOI: 10.1016/j.labeco.2005.05.010

Clark, S. L. \& Muthén, B. (2009). Relating latent class analysis results to variables not included in the analysis. [Unpublished manuscript]. Available at: https://www.statmodel.com/ download/relatinglca.pdf (referred: 17 Nov 2014).

Dariotis, J.K., Pleck, J.H., Astone, N.M. and Sonenstein, F.L. (2011) 'Pathways of early fatherhood, marriage, and employment: a latent class growth analysis', Demography 48(2): 593-623. DOI: 10.1007/s13524-011-0022-7

Datta Gupta, N., Smith, N. and Verner, M. (2008) 'PERSPECTIVE ARTICLE: The impact of Nordic countries' family friendly policies on employment, wages, and children', Review of Economics of the Household (6)1: 65-89. DOI: 10.1007/s11150-007-9023-0

Duvander, A.-Z., Haas, L. and Hwang, C. P. (2014) 'Sweden', in Moss, P. (ed.) 10 th International Review of Leave Policies and Related Research 2014, p. 291-300. Available at: http://www. leavenetwork.org/fileadmin/Leavenetwork/Annual_reviews/2014_annual_review_korr.pdf (referred: 29 Aug 2014).

Eurostat (2014) Employment statistics. Statistics explained. Available at: http://epp.eurostat.ec. europa.eu/statistics_explained/index.php/Employment_statistics\# (referred: 17 Nov 2014).

Fagan, C. and Norman, H. (2012) 'Trends and social divisions in maternal employment patterns following maternity leave in the UK', International Journal of Sociology and Social Policy 32(9/10): 544-560. DOI: 10.1108/01443331211257643

Forma, P., Saari, P., Tuomi, T. and Väänänen, J. (2008) Mainettaan parempi kuntatyö? [Work in the municipal sector - better than its reputation?] Helsinki: Kuntien eläkevakuutus (Keva).

Fouarge, D., Manzoni, A., Muffels, R. and Luijkx, R. (2010) 'Childbirth and cohort effects on mothers' labour supply: a comparative study using life history data for Germany, the Netherlands and Great Britain', Work, Employment and Society 24(3): 487-507. DOI: $10.1177 / 0950017010371651$ 
Gutiérrez-Domènech, M. (2005) 'Employment Transitions after Motherhood in Spain', Labour: Review of Labour Economics \& Industrial Relations 19(Supplement 1): 123-148. DOI: 10.1111/j.1467-9914.2005.00313.x

Haataja, A. and Juutilainen, V-P. (2014) 'Kuinka pitkään lasten kotihoitoa? Selvitys äitien lastenhoitojaksoista kotona 2000-luvulla'. [How long at home taking care of children? A report on mothers' child home care periods in the 2000s]. Työpapereita 58/2014. Helsinki: Social Insurance Institution of Finland, Research Department.

Hakovirta, M. and Salin, M. (2006) 'Valinta vai pakko? Kansainvälinen vertailu äitien preferoiman ja toteutuneen työmarkkina-aseman yhteydestä' [Choice or Constraint? An international comparison on the interrelation of mothers' preferred and actual labour market situation] Janus 14(3): 255-271.

Hofferth, S. L. and Curtin, S.C. (2006) 'Parental Leave Statutes and Maternal Return to Work After Childbirth in the United States', Work \& Occupations 33(1): 73-105. DOI: $10.1177 / 0730888405281889$

Huang, D.Y.C., Evans, E., Hara, M., Weiss, R.E. and Hser, Y-I. (2011) 'Employment trajectories: Exploring gender differences and impacts of drug use', Journal of Vocational Behavior 79(1): 277-289. DOI: 10.1016/j.jvb.2010.12.001

Hynes, K. and Clarkberg, M. (2005) 'Women's employment patterns during early parenthood: A group-based trajectory analysis', Journal of Marriage and Family 67(1): 222-239. DOI: $10.1111 / \mathrm{j} .0022-2445.2005 .00017 . x$

Jung, T. and Wickrama, K.A.S. (2008) 'An Introduction to Latent Class Growth Analysis and Growth Mixture Modeling', Social and Personality Psychology Compass 2(1): 302-317. DOI: $10.1111 / \mathrm{j} .1751-9004.2007 .00054 . \mathrm{x}$

Kellokumpu, J. (2006) Lasten vaikutus äidin palkkaan. [The effect of children on mothers' wages]. Helsinki: Labour Institute for Economic Research.

Kivimäki, M., Gimeno, D., Ferrie, J.E., Batty, G.D., Oksanen, T., Jokela M., Virtanen, M., Salo, P., Akbaraly, T.N., Elovainio, M., Pentti, J. and Vahtera, J. (2009) 'Socioeconomic position, psychosocial work environment and cerebrovascular disease among women: the Finnish public sector study', International Journal of Epidemiology 38(5): 1265-1271. DOI: $10.1093 /$ ije/dyn373

Lambert, D. (1992) 'Zero-inflated Poisson regression, with an application to defects in manufacturing', Technometrics 34(1): 1-14. DOI: 10.1080/00401706.1992.10485228

Lehto, A. and Sutela, H. (2009) Three decades of working conditions: Findings of Finnish Quality of Work Life Surveys 1977-2008. Helsinki: Statistics Finland.

Lo, Y., Mendell, N.R. and Rubin, D.B. (2001) 'Testing the number of components in a normal mixture', Biometrika 88(3): 767-778. DOI: 10.1093/biomet/88.3.767

Miettinen, A. and Manninen, A. (2006) Sovittelua ja sopeutumista. Työn ja perheen ybteensovittamisen kysymyksiä määräaikaista tai osa-aikatyötä tekevien perheissä. [Combining work and family in families with temporary or part-time jobs] Reviews E23/2006. Helsinki: Family Federation of Finland, Population Research Institute.

Mplus Technical Appendices (2010) Wald Test of Mean Equality for Potential Latent Class Predictors in Mixture Modeling. Available at: http://statmodel.com/download/meantest 2 . pdf (referred: 29 Aug 2014).

Muthén, L.K. and Muthén, B.O. (1998-2012) Mplus User's Guide. Seventh Edition. Los Angeles, CA: Muthén \& Muthén.

Nagin, D.S. (2005) Group-Based Modeling of Development. London: Harvard University Press.

Nagin, D.S. and Land, K.C. (1993) 'Age, criminal careers, and population heterogeneity: specification and estimation of a nonparametric, mixed Poisson model', Criminology 31(3): 327-362. DOI: 10.1111/j.1745-9125.1993.tb01133.x

Närvi, J. (2014a) Määräaikainen työ, vakituinen vanhemmuus. Sukupuolistuneet työurat, perheellistyminen ja vanhempien hoivaratkaisut. [Temporary employment, permanent 
parenthood. Gendered careers, family formation and parents' care decisions] Research 122. Helsinki: National Institute for Health and Welfare.

Närvi, J. (2014b) 'Äidit kotona ja työssä - perhevapaavalinnat, työtilanteet ja hoivaihanteet’ [Mothers at home and at work - family leave choices, employment situations and child care ideals], Yhteiskuntapolitiikka 79(5): 543-552.

Närvi, J. (2012) 'Negotiating care and career within institutional constraints - work insecurity and gendered ideals of parenthood in Finland', Community, Work \& Family 15(4): 451-470. DOI: 10.1080/13668803.2012.724827

Nylund, K.L., Asparouhov, T., and Muthén, B.O. (2007) 'Deciding on the Number of Classes in Latent Class Analysis and Growth Mixture Modeling: A Monte Carlo Simulation Study', Structural Equation Modeling: A Multidisciplinary Journal 14(4): 535-569. DOI: 10.1080/10705510701575396

Peutere, L., Haataja, A., Vahtera, J., Kivimäki, M., Pentti, J. and Virtanen, P. (2014) 'Heikentääkö kotihoidon tuen kuntalisä äitien kiinnittymistä työelämään?' [Does the municipal supplement for child home care allowance weaken mothers' labour market attachment?], Yhteiskuntapolitiikka 79(3): 291-305.

Palanko-Laaka, K. (2005) Määräaikaisen työn yleisyys, käytön lainmukaisuns ja lainsäädännön kehittämistarpeet. [The frequency of fixed-term employment, the legality of its use and the needs for developing legislation] Helsinki: Ministry of Labour.

Pfau-Effinger, B. (1993) 'Modernisation, Culture and Part-Time Employment: The Example of Finland and West Germany', Work, Employment and Society 7(3): 383-410. DOI: 10.1177/095001709373003

Pfau-Effinger, B. (2012) 'Women's employment in the institutional and cultural context', International Journal of Sociology and Social Policy 32(9/10): 530-543. DOI: 10.1108/ 01443331211257634

Repo, K. (2010) 'Finnish child home care allowance - users' perspectives and perceptions' In: Sipilä, J., Repo, K. and Rissanen, T. (Eds), Cash-for-Childcare: The Consequences for Caring Mothers. Cheltenham: Edward Elgar Publishing, p. 46-64.

Rissanen, T. (2012) 'Kotiin, töihin, työttömäksi - siirtymät työelämän ja kotihoidon tuen välillä' [At home, employed, or unemployed - transitions between working life and home care leave] In: Sipilä, J., Rantalaiho, M., Repo, K. and Rissanen, T. (Eds.), Rakastettu ja vihattu lasten kotihoidon tuki [Loved and hated child home care allowance] Jyväskylä: Vastapaino, p. 151-181.

Rønsen, M. and Sundström, M. (2002) 'Family Policy and After-Birth Employment Among New Mothers - A Comparison of Finland, Norway and Sweden' European Journal of Population 18(2): 121-152. DOI: 10.1023/A:1015532305179

Salmi, M. and Lammi-Taskula, J. (2014) 'Finland', in Moss, P. (ed.) $10^{\text {th }}$ International Review of Leave Policies and Related Research 2014, p. 117-130. Available at: http://www. leavenetwork.org/fileadmin/Leavenetwork/Annual_reviews/2014_annual_review_korr. pdf (referred: 29 Aug 2014).

Salmi, M., Lammi-Taskula, J. and Närvi, J. (2009) Perhevapaat ja työelämän tasa-arvo [Family Leave and Gender Equality in Working Life]. Helsinki: Ministry of Employment and the Economy.

Saurel-Cubizolles, M., Romito, P., Escribà-Aguir, V., Lelong, N., Mas Pons, R. and Ancel, P-Y. (1999) 'Returning to Work after Childbirth in France, Italy, and Spain', European Sociological Review 15(2): 179-194.

Shapiro, D. and Mott, F. L., (1994) 'Long-Term Employment and Earnings of Women in Relation to Employment Behavior Surrounding the First Birth', Journal of Human Resources 29(2): 248-275.

Simonson, J., Romeu Gordo, L., and Titova, N. (2011) 'Changing employment patterns of women in Germany: How do baby boomers differ from older cohorts? A comparison us- 
ing sequence analysis' Advances in Life Course Research 16(2): 65-82. DOI: 10.1016/j. alcr.2011.03.002

Statistics Finland (2013a) Labour force survey 2013. Families and work. 3. Labour market position of parents in families with children. Helsinki: Statistics Finland. Available at: http://stat.fi/til/tyti/2013/14/tyti_2013_14_2014-10-07_kat_003_en.html (referred: 24 Nov 2014).

Statistics Finland (2013b) Labour force survey 2013. Families and work. 4. Large share of mothers at home caring for children without employment contract. Helsinki: Statistics Finland. Available at: http://www.stat.fi/til/tyti/2013/14/tyti_2013_14_201410-07_kat_004_en.html (referred: 24 Nov 2014).

Statistics Finland (2010a) Labour force survey. Time series data 2001-2010. Appendix table 23. Unemployment rates by age and sex in 2001-2010. Helsinki: Statistics Finland. Available at: http://tilastokeskus.fi/til/tyti/2010/16/tyti_2010_16_2011-11-01_tau_023_ en.html (referred: 9 Jan 2014).

Statistics Finland (2010b) Labour force survey. Time series data 2001-2010. Appendix table 17. Employees aged 15-74 in permanent and temporary (fixed-term) employment relationship by sex in 2001-2010, \%. Helsinki: Statistics Finland. Available at: http:// tilastokeskus.fi/til/tyti/2010/16/tyti_2010_16_2011-11-01_tau_017_en.html (referred: 9 Jan 2014).

Statistics Finland (1987) Classification of Occupations. Helsinki: Statistics Finland.

Sund, R. (2012) 'Quality of the Finnish Hospital Discharge Register: A systematic review', Scandinavian Journal of Public Health 40(6): 505-515. DOI: 10.1177/1403494812456637

Vlasblom, J.D. and Schippers, J. (2006) 'Changing dynamics in female employment around childbirth: evidence from Germany, the Netherlands and the UK', Work, Employment and Society 20(2): 329-347. DOI: 10.1177/0950017006064117

Virtanen, P., Lipiäinen, L., Hammarström, A., Janlert, U., Saloniemi, A. and Nummi, T. (2011) 'Tracks of labour market attachment in early middle age: A trajectory analysis over 12 years', Advances in Life Course Research 16(2): 55-64. DOI: 10.1016/j.alcr.2011.03.001

\section{End note}

1 Since 2005, earnings-related pension has been accrued from all paid work and work in a self-employed capacity between the ages of 18 and 67. Although before 2005 the age limit for starting to accrue earnings-related pension was 23 , information on employment contracts is also available for younger employees. 